\title{
Smart City in Practice: Learn from Taipei City
}

\author{
Muhammad Iqbal \\ Department of Political Science, National Cheng Kung University, Taiwan \\ Corresponding Author: u18097019@ncku.edu.tw \\ doi) http://dx.doi.org/10.18196/jgpp.811342 \\ Article Info
}

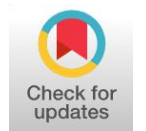

Article History;

Received:

2021-01-12

Revised:

2021-02-23

Accepted:

2021-02-27

\begin{abstract}
The main aspects of building a smart city according to Frost and Sullivan in 2014 are smart governance, smart technology, smart infrastructure, smart healthcare, smart mobility, smart building, smart energy and smart citizens. The smart city's purpose is to form a comfortable, safe city and strengthen its competitiveness. Based on these indicators, Taipei City can become one of the cities with the best Smart City implementation globally. This article uses a qualitative approach with literature review techniques in data collection. This study's findings indicate that the Smart Education, Smart Transportation, Smart Social Housing and Smart Healthcare policies are essential policies in supporting the successful implementation of smart cities in Taipei City. The four main pillars in implementing smart city in Taipei City have integrated Artificial intelligence and big data in smart city governance in Taipei City.
\end{abstract}

Keyword: Smart City; Artificial Intelligence; Taipei City.

\section{INTRODUCTION}

The increasing flow of urbanization creates new problems for urban or urban areas. They are starting from waste, education, transportation, socio-economy, disasters, and health. On the other hand, increasingly modern and established society has a myriad of expectations, such as a comfortable living and working environment, adequate public areas, and the ease of managing all forms of public services (Pan, et,al, 2011). Smart cities are becoming a trend in various countries in the world. It is a form of prestige called a smart city, but smart city is an excellent step in advancing cities in a country based on Information and Communication Technology (ICT) (Clohessy, et.al, 2014). The smart city is defined as a smart city with a concept designed in such a way as to benefit the community, especially in managing resources to be efficient and effective (Cardullo \& Kitchin, 2019).

The main aspects of building a smart city according to Frost and Sullivan (Evans, et.al, 2019) are smart governance, smart technology, smart infrastructure, smart healthcare, smart mobility, smart building, smart energy and smart citizens. The smart city's purpose is to form a comfortable, safe city and strengthen competitiveness in the economy. Cities are entities that attract the attention of many researchers (Shamsuddin \& Srinivasan, 2020). Not only because cities have such fast-changing dynamics, but also because many predictions are based on research results that nearly $50 \%$ of the world's population will populate cities (Bakıcl, et.al., 2013; Chourabi, et.al., 2012). As a result, cities are increasingly facing enormous and complex challenges related to the facilities provided to their citizens. Basic needs such as health, education, public transportation, so that city residents feel the safety, comfort and happiness of living in their city must be met by city managers (Hodgkinson, 2011; Picioroagă, et.al, 2018).

Figure.1 explain the development of increasingly smart technology makes the concept of smart not only applied to various devices but various systems or arrangements (Yang, et.al, 2016; Kencono \& Iqbal, 2021). The idea known as a smart city is a concept that presents a smart city structure that can play a role in making it easier for people to get information quickly and 
accurately. The idea of a smart city is presented as an answer to efficient resource management. The concept of a smart city is the direct integration of information with urban communities.

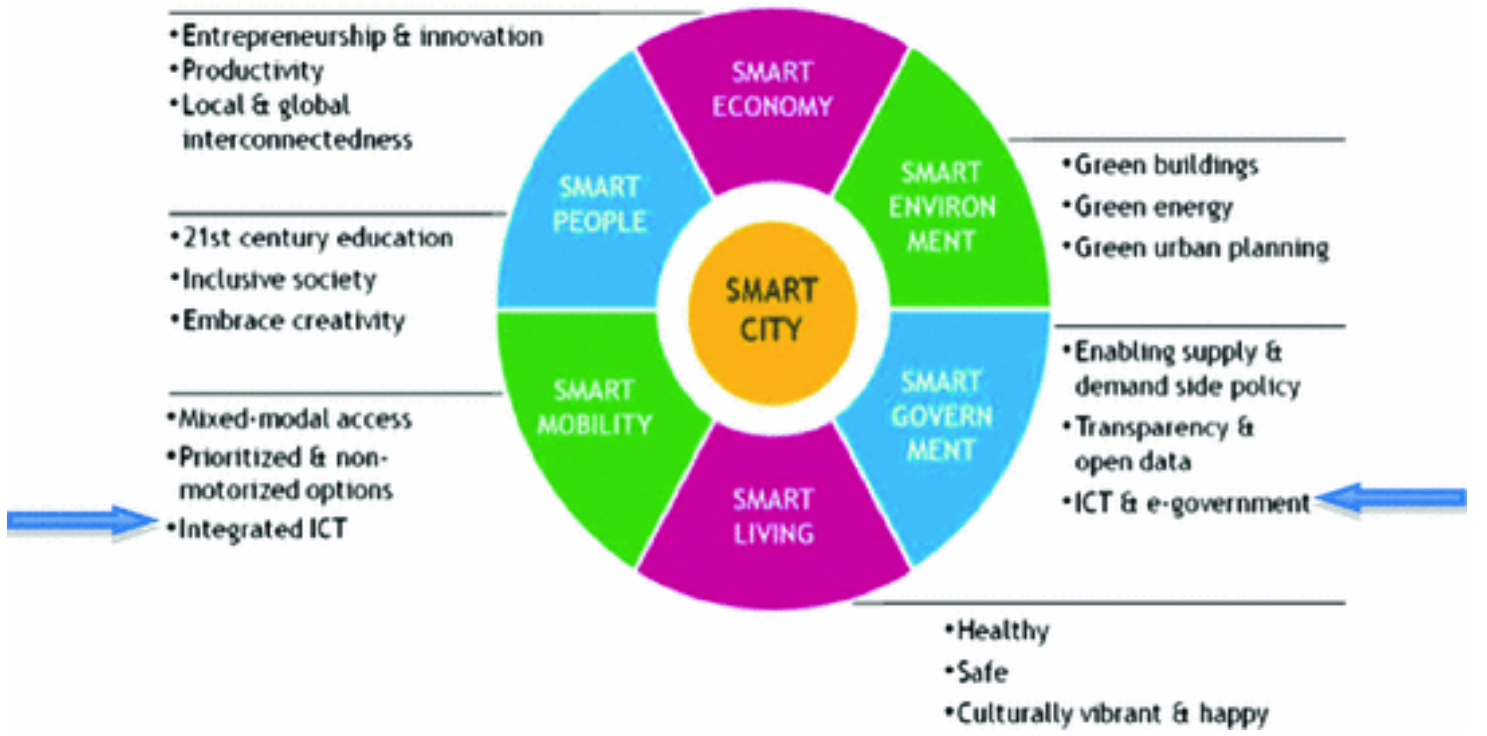

Figure.1 The Smart city wheel model. Source: (Wu, et., al, 2018)

Many previous researchers were created smart city development concepts Wang \& Wu, 2016; Anthopoulos, 2015). (Yin, 2015) Described application domain classification of smart city: government, citizen, business and environment as show at Table 1. Similarly, the smart city development overlays the existing infrastructure with sensors and intelligent software and connects it to a larger system. As systems become more heterogeneous, interconnected and dependent on software, the challenge of producing stable, robust and secure devices and infrastructures gets magnified. Interoperability includes both technical and cognitive abilities, and advancing it requires agreements on how to join the sub-systems.

Table 1. Domain Classification of Smart City

\begin{tabular}{|c|c|c|}
\hline Domain & Sub-Domain & Description \\
\hline $\begin{array}{l}\text { Government } \\
\text { (more efficient) }\end{array}$ & $\begin{array}{l}\text { E-government, } \\
\text { Transparent government, } \\
\text { Public service Public safety, } \\
\text { City monitoring Emergency } \\
\text { response }\end{array}$ & $\begin{array}{l}\text { Improving the internal and external efficiency of the } \\
\text { government; enabling citizens and other relevant } \\
\text { organizations to access official documents and policies; } \\
\text { ensuring that public services work efficiently; } \\
\text { monitoring and managing public safety; responding } \\
\text { quickly and effectively in emergency situations }\end{array}$ \\
\hline $\begin{array}{l}\text { Citizen } \\
\text { (happier) }\end{array}$ & $\begin{array}{l}\text { Public transport, Smart } \\
\text { traffic Tourism, } \\
\text { Entertainment, Healthcare, } \\
\text { Education, Consumption, } \\
\text { Social cohesion }\end{array}$ & $\begin{array}{l}\text { Traveling and moving more efficiently; accessing } \\
\text { contextualized, precise, realtime information in daily life; } \\
\text { high-quality essential public services such as education, } \\
\text { healthcare and sport; enriching spare time activities, } \\
\text { communicating and sharing more with others }\end{array}$ \\
\hline $\begin{array}{l}\text { Business (more } \\
\text { prosperous) }\end{array}$ & $\begin{array}{l}\text { Enterprise management, } \\
\text { Logistics, Supply chain, } \\
\text { Transaction, } \\
\text { Advertisement, Innovation, } \\
\text { Entrepreneurship, } \\
\text { Agriculture }\end{array}$ & $\begin{array}{l}\text { Improving inter management efficiency and quality; } \\
\text { using more efficient logistics and supply chain platforms } \\
\text { and methods; advertising more widely and accurately; } \\
\text { expanding trade partners and customers; facilitating } \\
\text { entrepreneurship and investment; upgrading the } \\
\text { business activity in a city, such as production, commerce, } \\
\text { agriculture and consulting; fostering innovation }\end{array}$ \\
\hline $\begin{array}{l}\text { Environment } \\
\text { (more } \\
\text { sustainable) }\end{array}$ & $\begin{array}{lr}\text { Smart grid, } & \text { Renewable } \\
\text { energy, } & \text { Water } \\
\text { management, } & \text { Waste } \\
\text { management, } & \text { Pollution } \\
\text { control, Building, Housing, } & \text { Hommunity, Public space }\end{array}$ & $\begin{array}{l}\text { Delivering more sustainable, economic and secure } \\
\text { energy and water supplies by taking into account } \\
\text { citizens' behavior; using more green or renewable } \\
\text { energy; recycling and treating waste efficiently and } \\
\text { safely; reducing and preventing pollution in the city; } \\
\text { offering mobility, telecommunication, information and } \\
\text { all other facilities in different city spaces. }\end{array}$ \\
\hline
\end{tabular}


According to the IMD Smart City Index Survey Report (2019) organized by the Switzerland International Institute for Management Development (IMD) and the Singapore University of Technology and Design, Taipei City is ranked as the 7th largest smart city the world. In the last two years, IMD has conducted an assessment of 102 cities around the world. Unlike other smart city indicators that focus more on the analysis and evaluation of experts and scholars, IMD also takes samples and interviews, 120 residents, in each city, with the most intuitive and accurate citizen perceptions for assessing city hardware and software services the. One of the questions asked was, "Does the government focus on public needs and use technology to improve people's lives?" The proper use of technology is one of the primary keys in determining whether a city can be classified as a "smart" city (Chang, et.al, 2021).

According to the "2019 IMD Global Smart City Index" report, Taipei received an overall rating of "A", and is ranked seventh globally, ahead of internationally renowned cities such as Amsterdam, San Francisco, Vancouver, Sydney, Prague and Tokyo. In this ranking, Taipei is also ranked second in Asia's "Smart City" after Singapore, while Hong Kong, (Asia's third rank) is ranked thirty-seventh globally. In the 36 indicators contained in the report, it is known that Taipei City residents get convenience in the field of public information about arts and cultural activities, free public Wi-Fi services, recycling services, health resources, the convenience of buying tickets for public transportation tickets, and registration for efficient medical services (Wu, et.al, 2020).

Other aspects that have also received appreciation from the community include opportunities to participate in and supervise city policies and budgets through an open platform, management of household documents through online media, provision and repair of public facilities, a comprehensive surveillance system to protect citizen safety providing services for startup entrepreneurs through easy online services, as well as other services that demonstrate the results of implementing the smart city policy in Taipei (Wu, 2020).

The purpose of this study is to analyze the application of Smart City in Taipei City. In this context, Taipei City is a city that is successful in implementing a Smart City. Taipei City's success is expected to be a reference for other countries in implementing Smart City in their country.

\section{RM: How is the implementation of smart city policy in Taipei City?}

\section{RESEARCH METHOD}

This research is a descriptive qualitative study, which was conducted to describe the problem being studied and objectively integrate the data in the study site. Qualitative research methods are a series of research procedures that produce descriptive data in the form of words both written and oral about the nature of individuals, situations, symptoms of groups, or even specific groups that are being observed (Moleong, 2004). Researchers choose to use this method because it is very suitable to be used in the process of finding data to answer existing problems and support research needs. The type of data used in this study is secondary data obtained from the literature study results, official government data, as well as news and documentation that can support and complete research analysis materials. The data collected are then sorted in order to answer research problems.

\section{RESULT AND DICUSSION}

\section{Smart Education}

Taipei City Government participated Smart City Asia Pacific Awards (SCAPA) host by IDC Asia/Pacific and become one of the winners with the project "Crossing Learning Barriers: Omni Smart Education" in the category of education. The awards were composed of 6 stages of strict reviews and it is the first time for both Taipei and Taiwan to be awarded in this category. Taipei City Government has been investing in smart education since 2018 with a budget approximately of 1.6 billion NTD in the 4 main fields as follow: setting up smart network in campuses, setting up smart future classrooms, promoting digital learning platforms, and promoting mobile studying and smart teaching. Taipei City Government aims to provide diversified yet integrated education services for students, parents and teachers. Taipei City Government work to 
empower students of the autonomous learning, encourage teachers to apply innovated teaching, and to improve the interactions between parents and teachers with the aid of technology.

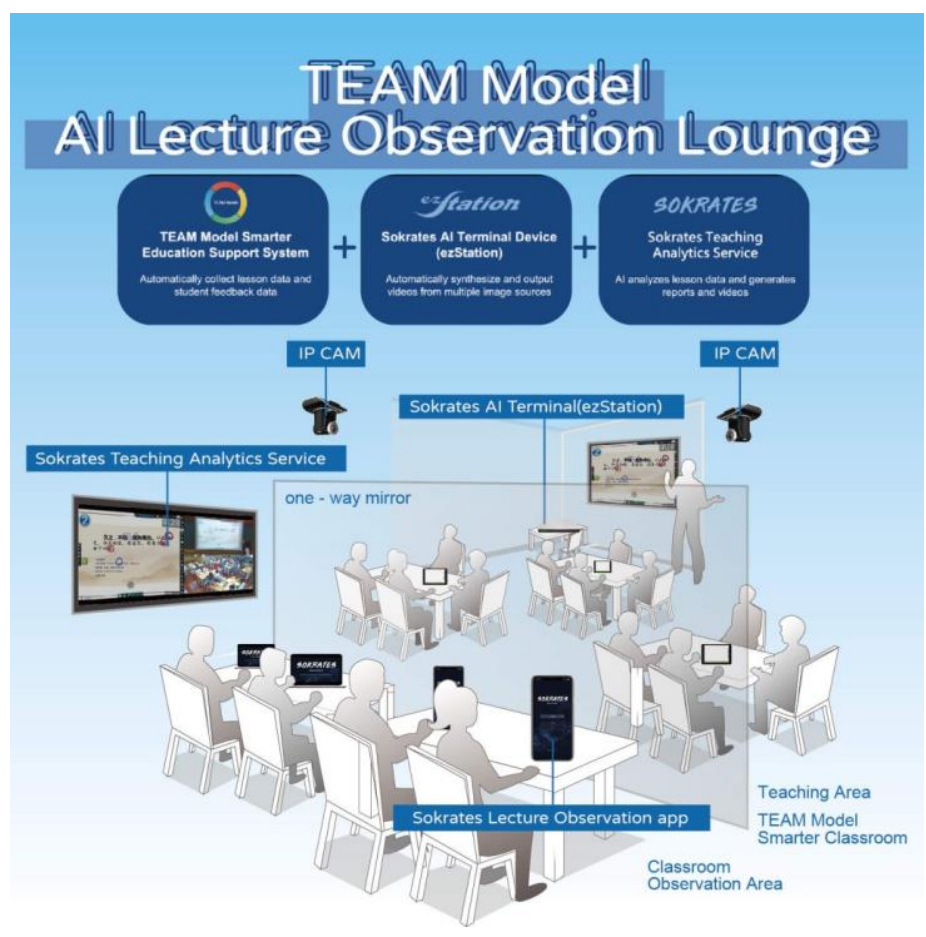

Figure.2 Illustration of Smart Education in Taipei City Source: https://en.smartcity.org.tw/index.php/en-us/

Based on Figure.2 TEAM Model Smarter Classroom is a kind of smarter classroom based on HiTeach Smarter Teaching System, which is also the basic constituent unit of AI school. Starting with "teaching" and "learning" in class, TEAM Model Smarter Classroom perfectly integrates all kinds of software, hardware and cloud AI, big data required in the class. Without complicated operation, it can help teachers and students to achieve the ideal state of modern classroom and flip the traditional teaching scene.

Digitalization in education is also an essential pillar in implementing smart city policies in Taipei City. Supporting the findings of Zhu \& Riezebos (2016) Smart education implemented by Taipei City aims to improve learners' quality of lifelong learning. This phenomenon shows the importance of Science and Technology in applying Smart Education in advancing adequate Human Resources in the future era (Makarova, et. al, 2018). Several collaborative programs launch evidence this with smart education in implementing Smart City.

\section{Smart Transportation}

Taiwan's current situation in Smart Transportation: Taipei has been developing ITS for more than 27 years. From the first tier of Infrastructure Development (1990-), the second tier of Services Systematization (1999-), the third tier of Sharing ITS Services (2000-), the fourth tier of Inauguration of Smart City Program (2014-), and the fifth tier of Smart City Lifestyle (2017-). It is expected that the future of the city will be improved by ITS technology and management thinking, inspection of people's needs, inter-regional cooperation, integration of transport facilities and proper application of information technology. From 1990, Taipei City Government have applied innovative technology and information to solve the problems of the public and to construct the government, the public and the industrial co-existence system. In the future, Taipei will be a "living lab" that can provide more intelligent services for people. The citizens in Taipei will enjoy a smart city lifestyle (Chang, Jou and Chung, 2021).

Taiwan's strength in Smart Transportation: Taipei Smart City Lifestyle in Transportation mainly includes several -12- services: bike, bus, Metro. There are 400 stations and 13 thousand 
bikes for bike sharing system (Youbike). About 5-10 minutes walking distance, the people can find a Youbike station. The people can find where to rent or park in APP. More than $500 \mathrm{~km}$ bike lanes exist in Taipei area. The People can rent a bike easily to travel in the city. Comprehensive and Smart Bus Services connect everyone. There are 3,313 buses and 286 routes in Taipei. $97.5 \%$ of land area is covered by public transport, with only a 500-meter walk to reach a bus stop. Everyday 1.3 million people take bus to the destination. Taipei City Government requested all buses to install the GPS system, and use the GPS data to create a dynamic bus information system. Passengers get bus real arrival time at bus stops or on mobile phone from dynamic bus information system. The accuracy rate of smart bus system is over 95\%. Reliable Smart MRT system saves the people time. Now, the MRT system have 5 lines, 117stations. There are 2 million passengers a day. MRT trains and stations offer public WIFI services for passengers. On time performance is $99.6 \%$. With its smart train control and management systems, Taipei MRT's reliability index (MKBF) was the best in the world for a consecutive five years (Chang, et.al, 2020).

Figure.3 explain Taipei City Government cooperated with Turing Drive Co. Ltd. to initiate a midnight self-driving bus test on the bus lane of Xinyi Road. From May, this test will verify the various scenarios that may face in the future. According to the results, the test will be gradually to carry passengers, and the public will experience the test ride as soon as September this year. Turing Drive Co. Ltd. is a new domestic team that specializes in the development of autonomous driving systems, combining deep learning, sensor fusion, parallel computing, and vehicle dynamic control technologies (Babar and Arif, 2019).

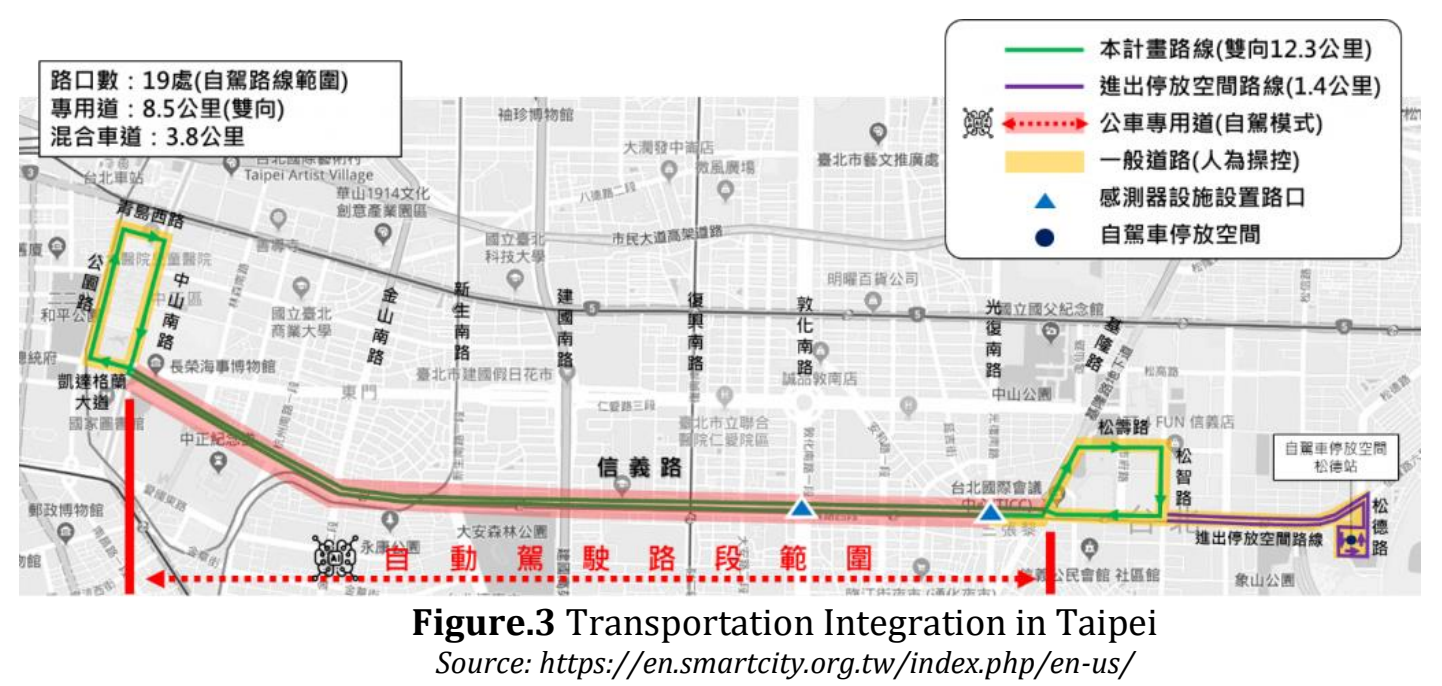

\section{Smart Healthcare}

The Department of Health, Taipei City Government (hereafter, referred to as "the Department") has been dedicated to promoting "Smart Healthcare". Considering the available medical resources and facilities in Taipei, the Taipei City Hospital is the top choice in conducting research projects and experiments for "Smart Healthcare". The Hospital has taken the initiative to coordinate all resources, through increasing the amount of self-developed projects, contracting establishments, field experiments, human research and clinical trials. By cooperating with the industry, schools and research institutes, the Hospital can accelerate the process of intellectualization and digitalization of hospital management and healthcare. For example, to face the issue of high prevalence among non-communicable diseases, including diabetes mellitus and dementia, the Hospital has developed the "Cloud Hospital" platform, promoted the intellectual case management system and provided telemedicine services (Yang, et.al, 2016).

For outlying islands, the Lien-Chiang County, the Hospital can verify patients with a cell phone APP, allowing them to make appointments with a specialist for telemedicine services. In addition, the clinical unit at the Hospital assists in checking the inventory of current mobile 
medical devices and organizing the clinical needs and suggestions from each medical unit for further device development references. As the healthcare provider, the Hospital also purchased other mobile medical devices, including the integrated portable slit lamp, ophthalmoscope, ophthalmology mobile medical cart and tablet-based ultrasound machine, to improve the medical and community health screening quality and patient satisfaction. By cooperating in research projects and field experiments, the Hospital supports companies to develop and experiment with artificial intelligence (AI) medical imaging device or interpretation systems, such as prospective X-ray, CT and MRI (Chen, et.al, 2020). In order to continually improve hospital management, the clinic registration system, broadcast system and visualization system at the nursing station have been introduced to the Hospital.

Furthermore, huge amount of resources and budgets have been invested in electronic medical records, strategic analysis, data application and information sharing, such as connecting the dialysis system with the machine to upload data, establishing a database with medical record information and "Decision Assisting System", and Big data analysis on psychiatric and traditional medicine etc. Recently, the "Blockchain" technique has been applied on the development of the "Integrated Care Information Platform", allowing physicians to design a patient-centred and family-focused treatment plan. Patients can consent via their phones, which gives permission to their physicians to review their medical records from other hospitals, and patients can also look up and revise their authorization status anytime. been invested in electronic medical records, strategic analysis, data application and information sharing, such as connecting the dialysis system with the machine to upload data, establishing a database with medical record information and "Decision Assisting System", and Big data analysis on psychiatric and traditional medicine etc. Recently, the "Blockchain" technique has been applied on the development of the "Integrated Care Information Platform", allowing physicians to design a patient-centred and family-focused treatment plan. Patients can consent via their phones, which gives permission to their physicians to review their medical records from other hospitals, and patients can also look up and revise their authorization status anytime (Chen, et.al, 2020).

Taiwan's strength in Smart Healthcare Based on the results of the "Global Views Monthly" magazine, "2019 General Competitiveness Survey among all Counties and Cities in Taiwan", Taipei is ranked first in healthcare, compared to the other municipalities. As the capital city in Taiwan, the Department encompass mass resources and years of experiences in constructing a healthy city and is ready to integrate with the world.

\section{Smart Social Housing}

The goal is to ensure better performance and environmental quality of social housings under the premise of promoting Taipei City social housings as smart communities; ensure residents receive more timely and comprehensive cares in terms of safety, health care, comfort, and convenience; and to enhance the efficiency of life. As the world is facing environmental issues such as climate change and energy depletion, there is an urgent need to introduce smart strategies, sustainable environmental protection, and other relevant industrial technologies to help construct smarter and more environmentally friendly social housings (Tsuang and Peng, 2018).

In the future, Taipei City Government will apply smart technologies to design construction and management maintenance; and use the innovative planning concepts of ICT related technological development and Intelligent Building technology life applications to fulfill the various residential needs such as energy management, automation control, system integration, security surveillance, home care, and digital living. The goal is to perform a series of electronation, informatization and provide solutions by integrating innovative services. It is anticipated to guide the development of affordable housings followed by civil construction projects in order to achieve a win-win for the people, industry and the government. The government will use the demonstrative smart community as the Intelligent Building pioneer example to promote Intelligent Buildings that will in turn form smart communities and eventually develop into a smart city. It is expected to achieve the following 7 basic services: 
1. Provide social services: Child nursery, elderly care, employment services.

2. Provide healthy, sustainable, comfortable, convenient, energy-saving, and safe smart living spaces.

3. In addition to considering the urban texture, topography, and other base conditions; the architectural planning and design will also integrate architectural aesthetics, social art, smart green architecture, universal design, and safe utilization.

4. Smart property management for community safety and life management services will be introduced in terms of maintenance management.

5. Construct smart facilities; install smart water, electricity, and gas meters; and provide potable tap water directly from the Taipei Water Department.

6. Establish an infrastructure management cloud in each community base (including rack-type cloud service server, dual WAN firewall router, anti-virus software, system integration software, community website design and construction, mobile APP development, and other equipment) to upload the community-integrated system equipment (visitor service systems, security access control systems, energy management systems, community information, etc.) information to the community Cloud. Assign permissions and provide information query services to the community residents and management company personnel/units.

7. The community cloud software must be general standard communication protocol software in order to facilitate browse and query by the relevant personnel. As the smart social housing project has just been started for 2016, Taipei City Government have not yet participated in any relevant international competitions

Taiwan's strength in Smart Social Housing the Taipei City Government is promoting social housing by establishing 5 major visions:

1. practice residential justice;

2. implement urban aesthetics;

3. become a smart city industry experimental field;

4. create a new residential business model; and

5. manage community relations.

The goal is to provide high-quality and affordable living environment to the residents of Taipei. So architectural aesthetics, social art, and smart green architecture will be combined with the ICT-related industrial energy in Taiwan in terms of architectural planning to create a new generation of smart social housing. To implement this social housing development vision, the Taipei City Government has planned the social housing smart community demonstration base by investing an additional 3\%-5\% of the construction funds to build smart facilities and use smart technologies for the design, construction, management and maintenance of social housing. In addition to energy conservation, water conservation and community safety; we will also construct a smart community management Cloud, smart power grid, smart senior health homes, etc., so residents can receive more timely and comprehensive care in terms of safety, health, and comfort. According to the Xinglong Social Housing Zone 1 experiences; smart power grid and smart community operations can reduce electricity consumption by over 13\% compared to that of a general community. Mayor indicated that all social housings in Taipei City will be equipped with the relevant smart technology facilities and be upgraded to become smart communities. We can use various smart technologies, sustainable environmental protection methods and other relevant industrial technologies to achieve energy conservation, carbon reduction and environmental sustainability during urban development in response to the environmental issues worldwide such as climate change and energy depletion (Cassidy, Lan \& Lee, 2015).

\section{CONCLUSION}

Smart City's application in Taipei City is one of the best smart city applications in the world. Taipei City, through its smart city implementation programs, can beat big cities around the world. The policy of implementing smart city in Taipei City has integrated digital as the 
smart city's principles. Implementing the smart city policy in Taipei is measured through policies such as Smart Education, Smart Transportation, Smart Social Housing and Smart Healthcare. The Taipei city government launched the Smart Education policy focuses on four fields such as setting up smart networks in campuses, setting up smart future classrooms, promoting digital learning platforms, and promoting mobile studying and smart teaching. This policy aims to encourage teachers to apply innovated education and improve the interactions between parents and teachers with technology aid.

Besides the smart transportation policy in Taipei City From 1990, Taipei City Government has applied innovative technology and information to solve the public's problems and construct the government, the people, and the industrial co-existence system. Taipei will be a "living lab" that can provide more intelligent services for people in the future. The citizens in Taipei will enjoy a smart city lifestyle. In smart healthcare in Taipei City, the government is encouraging hospitals to develop health services based on artificial intelligence and big data. Besides, to deal with the high prevalence among non-communicable diseases, including diabetes mellitus and dementia, the Hospital has developed a "Cloud Hospital" platform, promoted intellectual case management systems and provided telemedicine services.

The smart social housing policy is also an essential pillar in implementing smart city in Taipei City. The Smart Social Housing policy in Taipei City has a goal is to ensure better performance and environmental quality of social housings under the premise of promoting Taipei City social housings as smart communities; ensure residents receive more timely and comprehensive cares in terms of safety, health care, comfort, and convenience; and to enhance the efficiency of life.

\section{ACKNOWLEDGEMENT}

Thank you for Department of Political Science National Cheng Kung University of Taiwan

\section{REFERENCE}

Alamsyah, N., Susanto, T. D., \& Chou, T. C. (2016, July). A comparison study of smart city in Taipei and Surabaya. In 2016 international conference on ICT for smart society (ICISS) (pp. 111-118). IEEE. https://doi.org/10.1109/ICTSS.2016.7792859

Anthopoulos, L. G. (2015). Understanding the smart city domain: A literature review. Transforming city governments for successful smart cities, 9-21. https://doi.org/10.1007/978-3-319-03167-5 2

Babar, M., \& Arif, F. (2019). Real-time data processing scheme using big data analytics in internet of things based smart transportation environment. Journal of Ambient Intelligence and Humanized Computing, 10(10), 4167-4177. https://doi.org/10.1007/s12652-018-0820-5

Bakıcı, T., Almirall, E., \& Wareham, J. (2013). A smart city initiative: the case of Barcelona. Journal of the knowledge economy, 4(2), 135-148. https://doi.org/10.1007/s13132-012$\underline{0084-9}$

Cardullo, P., Di Feliciantonio, C., \& Kitchin, R. (Eds.). (2019). The right to the smart city. Emerald Group Publishing. https://doi.org/10.1108/9781787691391

Cassidy, I., Lan, C., \& Lee, C. J. (2015). The dilemmas of social housing system in the face of property-led urban regeneration: Taipei's crossroad between housing and real estate. 한국주거학회 국제학술대회논문집, 201-201.

Chang, I. C. C., Jou, S. C., \& Chung, M. K. (2021). Provincialising smart urbanism in Taipei: The smart city as a strategy for urban regime transition. Urban Studies, 58(3), 559-580. https://doi.org/10.1177/0042098020947908

Chang, M. C., Chiang, C. K., Tsai, C. M., Chang, Y. K., Chiang, H. L., Wang, Y. A., ... \& Tseng, H. Y. (2020). AI City Challenge 2020-Computer Vision for Smart Transportation Applications. In 
Proceedings of the IEEE/CVF Conference on Computer Vision and Pattern Recognition Workshops (pp. 620-621). https://doi.org/10.1109/CVPRW50498.2020.00318

Chen, C., Loh, E. W., Kuo, K. N., \& Tam, K. W. (2020). The Times they Are a-Changin'-Healthcare 4.0 Is Coming!. Journal of medical systems, 44(2), 1-4. https://doi.org/10.1007/s10916019-1513-0 PMid:31867697

Chourabi, H., Nam, T., Walker, S., Gil-Garcia, J. R., Mellouli, S., Nahon, K., ... \& Scholl, H. J. (2012, January). Understanding smart cities: An integrative framework. In 2012 45th Hawaii international conference on system sciences (pp. 2289-2297). IEEE. https://doi.org/10.1109/HICSS.2012.615

Clohessy, T., Acton, T., \& Morgan, L. (2014, December). Smart city as a service (SCaaS): A future roadmap for e-government smart city cloud computing initiatives. In 2014 IEEE/ACM 7th International Conference on Utility and Cloud Computing (pp. 836-841). IEEE. https://doi.org/10.1109/UCC.2014.136

Evans, J., Karvonen, A., Luque-Ayala, A., Martin, C., McCormick, K., Raven, R., \& Palgan, Y. V. (2019). Smart and sustainable cities? Pipedreams, practicalities and possibilities. https://doi.org/10.4324/9781003120247

Hodgkinson, S. (2011). Is your city smart enough? Digitally enabled cities and societies will enhance economic, social, and environmental sustainability in the urban century. OVUM report, 2-11.

Kencono, D. S., \& Iqbal, M. (2021, January). Do Cultural Values Affect the Implementation of Smart Living Policy in Yogyakarta City?. In 4th International Conference on Sustainable Innovation 2020-Social, Humanity, and Education (ICoSIHESS 2020) (pp. 35-41). Atlantis Press.

Makarova, I., Shubenkova, K., Antov, D., \& Pashkevich, A. (2018, March). Digitalization of engineering education: From e-learning to smart education. In International Conference on Remote Engineering and Virtual Instrumentation (pp. 32-41). Springer, Cham. https://doi.org/10.1007/978-3-319-95678-7 4

Moleong, L. J., \& Edisi, P. R. R. B. (2004). Metodelogi penelitian. Bandung: Penerbit Remaja Rosdakarya.

Pan, J. G., Lin, Y. F., Chuang, S. Y., \& Kao, Y. C. (2011, May). From governance to service-smart city evaluations in Taiwan. In 2011 International Joint Conference on Service Sciences (pp. 334-337). IEEE. https://doi.org/10.1109/IJCSS.2011.74 PMid:22155687

Picioroagă, I. I., Eremia, M., \& Sănduleac, M. (2018, October). SMART CITY: Definition and evaluation of key performance indicators. In 2018 International Conference and Exposition on Electrical And Power Engineering (EPE) (pp. 217-222). IEEE. https://doi.org/10.1109/ICEPE.2018.8559763

Shamsuddin, S., \& Srinivasan, S. (2020). Just smart or just and smart cities? Assessing the literature on housing and information and communication technology. Housing Policy Debate, 1-24. https://doi.org/10.1080/10511482.2020.1719181

Tsuang, H. C., \& Peng, K. H. (2018). The Livability of Social Housing Communities in Taiwan: A Case Study of Taipei City. International Review for Spatial Planning and Sustainable Development, 6(3), 4-21. https://doi.org/10.14246/irspsd.6.3 4

Wu, S. M., Chen, T. C., Wu, Y. J., \& Lytras, M. (2018). Smart cities in Taiwan: A perspective on big data applications. Sustainability, 10(1), 106. https://doi.org/10.3390/su10010106

Wu, Y. C., Sun, R., \& Wu, Y. J. (2020). Smart city development in Taiwan: From the perspective of the information security policy. Sustainability, 12(7), 2916 https://doi.org/10.3390/su12072916 
Wu, S. S. (2020). Smart Taipei City: understanding policy motivations, approaches and implementation. In Smart Cities in Asia. Edward Elgar Publishing. https://doi.org/10.4337/9781788972888.00011

Wang, K. Y., \& Wu, C. M. (2016). Building an intelligent government, intelligent city, and intelligent citizenry through ICTs: Smart city innovations in New Taipei City, Taiwan. In Smarter as the New Urban Agenda (pp. 259-278). Springer, Cham. https://doi.org/10.1007/978-3-319-17620-8 14

Yang, Z., Zhou, Q., Lei, L., Zheng, K., \& Xiang, W. (2016). An IoT-cloud based wearable ECG monitoring system for smart healthcare. Journal of medical systems, 40(12), 1-11. https://doi.org/10.1007/s10916-016-0644-9 PMid:27796840

Yin, C., Xiong, Z., Chen, H., Wang, J., Cooper, D., \& David, B. (2015). A literature survey on smart $\begin{array}{lllll}\text { cities. Science } & \text { China Information }\end{array}$ https://doi.org/10.1007/s11432-015-5285-y

Zhu, Z. T., Yu, M. H., \& Riezebos, P. (2016). A research framework of smart education. Smart learning environments, 3(1), 1-17. https://doi.org/10.1186/s40561-016-0026-2 